\title{
Effects of platelet-activating factor and its differential regulation by androgens and steroid hormones in prostate cancers
}

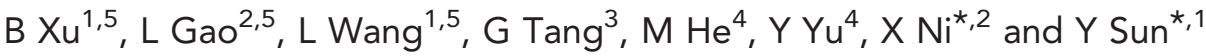

${ }^{1}$ Department of Urology, Changhai Hospital, Shanghai 200433, China; ${ }^{2}$ Department of Physiology, Second Military Medical University, Shanghai 200433, China; ${ }^{3}$ Department of Hematology, Changhai Hospital, Shanghai 200433, China and ${ }^{4}$ Department of Pathology, Changhai Hospital, Shanghai 200433, China

Background: Platelet-activating factor (PAF) is an arachidonic acid metabolite that plays an important role in cell proliferation, migration and neoangiogenesis, but whether it is involved in the progression of prostate cancer remains undiscovered.

Methods: Clinical prostate specimens were investigated with immunohistochemistry method and in vitro cell experiments referred to MTS cell proliferation assay, invasion and migration experiment, quantitative real-time RT-PCR assay, western blotting analysis and ELISA assay.

Results: Platelet-activating factor synthetase, lyso-PAF acetyl transferase (LPCAT1), increased significantly in castration-resistant prostate cancer (CRPC) specimens and CRPC PC-3 cells than that in controls. Intriguingly, PAF induced invasion and migration of PC-3 cells but not LNCaP cells. The PAF receptor antagonist inhibited proliferation of LNCaP and PC-3 cells. Dihydrotestosterone (DHT) treatment caused a decrease in LPCAT1 expression and PAF release in LNCaP cells, which could be blocked by androgen receptor antagonists. Finally, DHT increased LPCAT1 expression and PAF release in PC-3 cells in a Wnt/ $\beta$-catenin-dependent manner.

Conclusion: For the first time, our data supported that PAF might play pivotal roles in the progression of prostate cancer, which might throw a new light on the treatment of prostate cancer and the prevention of the emergence of CRPC.

Prostate cancer is the most common malignancy in American men and the second leading cause of male cancer mortality. In 2012, prostate cancer was expected to account for 29\% (241740) of all newly diagnosed cancers and 9\% (28 170) of all male cancer deaths (Siegel et al, 2012). The development and progression of prostate cancer are initially androgen dependent. Hence, androgen deprivation therapy (ADT) is generally employed to treat advanced or metastatic prostate cancer. However, prolonged androgen deprivation generally results in relapse and androgen-independent tumour growth (Dreicer et al, 2011). There is evidence that these castration-resistant tumours continue to depend on AR signalling, which may remain activated despite castrate levels of androgens and be responsible for tumour progression (Grasso et al, 2012). It is not well known, however, whether the responses of target genes to androgen are changed from androgen-dependant prostate cancer (ADPC) to castration-resistant prostate cancer (CRPC). Also, no effective treatment strategy for CRPC is now available in clinical practice.

The arachidonic acid (AA) pathway is a well-studied biological pathway that starts in cells at the plasma membrane of cellular organelles, where it is liberated by the action of PLA . Subsequently, AA is converted by COX to produce biologically active eicosanoids, prostaglandins. It is well established that $\mathrm{PGE}_{2}$, $\mathrm{PGF}_{2 \alpha}$ and thromboxane-2, the three main products generated by

\footnotetext{
${ }^{*}$ Correspondence: Dr Y Sun; E-mail: sunyinghao2012@gmail.com or Dr X Ni; E-mail: nixin@smmu.edu.cn
}

${ }^{5}$ These authors contributed equally to this work. 
COX-1 and COX-2, may contribute to prostate cancer tumourigenesis via induction of cell proliferation, angiogenesis, invasion and metastasis (Jain et al, 2008; Nie et al, 2008). However, unwanted side effects of COX inhibitors hampered its widespread use in the prevention of prostate cancer. Targeting other eicosanoids pathways during prostate cancer progression may represent an attractive new strategy for prostate cancer treatment.

Platelet-activating factor (PAF), a remodelling product of AA pathway, is converted by the enzyme acetyl coenzyme A: lyso-PAF acetyl transferase (LPCAT) from lyso-PAF, an immediate precursor catalysed by $\mathrm{CPLA}_{2}$. Platelet-activating factor then binds to PAF receptors and ultimately leads to the activation of gene expression, stimulating the $\mathrm{PLA}_{2}$ activities, calcium mobilisation, tyrosine phosphorylation and the generation of cyclic adenosine monophosphate (Jan and Chao, 2004). It has also been reported to be increased in a number of cancers, including human thyroid cancer, meningiomas, breast cancer and oesophageal cancer (Wang et al, 2002; Sato et al, 2010; Yu et al, 2012). It promotes migration, proliferation and neoangiogenesis in breast cancer cells (Bussolati et al, 2000). The activity of PAF was demonstrated in tissues of the prostate of rats (Muguruma et al, 1993). However, there have been no reports of PAF activity in normal human prostate tissue, human prostate cancer tissue or prostate cancer cell lines to date. In this study, we investigated whether PAF promotes proliferation and migration of prostate cancer cells and the regulation of LPCAT1 expression and PAF production by androgen and other steroid hormones in ADPC and CRPC cells.

\section{MATERIALS AND METHODS}

Materials. Dihydrotestosterone (DHT), flutamide, $17 \beta$-oestradiol, progesterone, RU486, MPP, cyclofenil, H89, chelerythrine chloride (CHE), wortmannin, triciribinehydrate, PAF and ABT-491 were obtained from Sigma Chemical Co. (St Louis, MO, USA). Dihydrotestosterone-carboxymethyloxime (CMO)-BSA was obtained from Steraloids (Newport, RI, USA). The PAF receptor polyclonal antibody was purchased from Cayman Chemical Co. (Ann Arbor, MI, USA). The LPCAT1 polyclonal antibody was purchased from Proteintech Group, Inc. (Chicago, IL, USA). Matrigel was purchased from $\mathrm{BD}$ Biosciences (Bedford, MD, USA). Transwell plates were obtained from Corning Inc. (Corning, NY, USA). The LNCaP and PC-3 cells were obtained from the American Type Culture Collection (The Institution of Biochemistry and Cell Biology, the Chinese Academy of Sciences, Shanghai, China).

Patients and samples. Study protocols involving human materials were approved by the institutional ethic committee of Changhai Hospital. Fresh prostate specimens were obtained immediately after radical prostatectomy of 12 localised prostate cancer cases. All patients had no prior long-standing ADT or anti-inflammatory treatment. Specimens were thickly sliced immediately. Samples cut from suspected cancerous areas and from apparently tumour-free areas were handled as previous described (Enayetallah et al, 2006), frozen in liquid nitrogen and stored at $-80^{\circ} \mathrm{C}$. Tumour tissues were dissected and separated from the frozen samples after a section of the cancer was pathologically confirmed, and only tumour cell-free samples were included as corresponding nontumour tissues. Standard histopathological diagnosis, and clinical staging based on the TNM system and Gleason scores, were assessed for each patient. All of them belonged to the stage of $\mathrm{PT}_{1 \mathrm{c}-2} \mathrm{~N}_{0} \mathrm{M}_{0}$ and the Gleason grade ranged from 6 to 9 . Nine paired frozen tumour and nontumour samples were homogenised in Trizol reagent (Invitrogen, Carlsbad, CA, USA), and total RNA was extracted and analysed using real-time PCR. Six CRPC specimens derived from TURP (transuretheral resection of prostate), and their matched ADT-naive ADPC specimens derived from biopsy, were obtained from the archives of the Department of Pathology, Changhai Hospital. The $6 \mathrm{CRPC}$ patients received ADT for a median time of 15 months before TURP. Clinicopathologic details of all 18 cases are described in Supplementary Table 1.

Immunohistochemistry. Immunohistochemical stain of LPCAT1 was performed as previously described (Xu et al, 2009). The sections were incubated with LPCAT1 antibody $(1: 100)$ and were detected with the biotin-streptavidin-peroxidase system (MaiXin Biotechnology, Fuzhou, China) using diaminobenzidine (Sigma-Aldrich, St Louis, MO, USA) as chromogen. Counterstaining was performed with haemalum.

Cell proliferation and invasion. LNCaP and PC-3 cells were cultured in RPMI-1640 medium containing 10\% fetal calf serum, 100 units of penicillin per $\mathrm{ml}$ and $100 \mathrm{mg}$ of streptomycin per $\mathrm{ml}$ at $37^{\circ} \mathrm{C}$ in a humidified atmosphere of $5 \% \mathrm{CO}_{2}$. Cell proliferation was determined using MTS Cell Proliferation Assay System (Promega, Madison, WI, USA) according to the manufacturer's instruction. Cells in each well received treatment with increasing concentrations of PAF and PAF antagonist ABT-491, or combinations of these agents. Controls received vehicle alone. After $96 \mathrm{~h}$ of incubation, $20 \mu \mathrm{l}$ of CellTiter 96 AQueous One Solution Reagent (Promega) was added into each well of the 96-well assay plate containing the samples in $100 \mu$ l of culture medium. The plate was incubated at $37^{\circ} \mathrm{C}$ for $4 \mathrm{~h}$ and absorbance was recorded the at $490 \mathrm{~nm}$ using a 96-well plate reader (Bio-Rad, Hercules, CA, USA).

A modified Boyden chamber was used to measure prostate cancer cell invasion. Briefly, Matrigel was thawed overnight at $4{ }^{\circ} \mathrm{C}$ and diluted 1:50 into RPMI-1640 medium (phenol red-free). The solution $(100 \mu \mathrm{l})$ was added to the upper surface of Transwell membrane inserts and was allowed to solidify in a sterile environment for $24 \mathrm{~h}$. The PC-3 or LNCaP cells $\left(10^{5}\right.$ cells per $\mathrm{ml}$ ) were suspended in RPMI-1640 medium and pretreated with the inhibitor ABT-491 $\left(10^{-5} \mathrm{M}\right)$ for $30 \mathrm{~min}$. Control cultures were treated with equivalent amounts of vehicle. Cells were then plated onto the surface of the inserts in a total volume of $100 \mu$ l. The RPMI-1640 medium supplemented with $10^{-9}-10^{-6} \mathrm{M}$ PAF $(400 \mu \mathrm{l})$ was added to the lower chamber. Cells were incubated at $37^{\circ} \mathrm{C}$ for $24 \mathrm{~h}$, followed by a 30 -s fixation in $100 \%$ methanol, and stained for $3 \mathrm{~min}$ by incubating with DAPI. The wells were then counted by using an inverted Olympus IX-55 microscope (Olympus, Tokyo, Japan). A total of 10 high-power $(\times 200)$ fields were recorded per insert. Migration assay was conducted with the non-matrigel-coated transwells using the same method. The number of cells migrating was calculated as the mean count per high-power field.

Cell cytotoxicity assay. For assessment of cytotoxicity, lactate dehydrogenase $(\mathrm{LDH})$ release into the extracellular medium was measured using the CytoTox 96 Non-Radioactive Cytotoxicity Assay Kit (Promega), following the manufacturer's instructions.

Quantitative real-time RT-PCR. Following different treatments, total RNA was extracted and quantified by quantitative real-time RT-PCR as previously described (Xu et al, 2009). Specific primers for the amplification were $5^{\prime}$-AAAGCTGACCCACCCAATAAC- ${ }^{\prime}$ and $5^{\prime}$-CCAATCAGAGGGACTTGTGC-3' for LPCAT1 (accession number NM_017839); and 5'-TGGCACCCAGCACAATGAA-3' and $5^{\prime}$-CTAAGTCATAGTCCGCCTAGAAGCA- $3^{\prime}$ for $\beta$-actin. Real-time PCR was carried out using Rotor-Gene 3000 (Corbett Research, Sydney, Australia) with ${ }^{\Delta \Delta}$ Ct method, according to the manufacturer's instructions. PCR reaction was set at $94^{\circ} \mathrm{C}(20 \mathrm{~s})$, $60(30 \mathrm{~s})$ and $72^{\circ} \mathrm{C}(30 \mathrm{~s})$ in a total of 40 cycles with a final extension step at $72^{\circ} \mathrm{C}$ for $5 \mathrm{~min}$.

Western blotting analysis. Protein expression levels were determined by western blotting as described before (Xu et al, 2009), in 
which membranes were incubated with anti-PAF receptor antibody (1:200 dilution in TBST with $5 \%$ non-fat milk) or anti-LPCAT1 antibody (1:1000 dilution in TBST with 5\% non-fat milk). The intensities of light-emitting bands were detected and quantified using Sygene Bio Image system (Synoptics Ltd, Cambridge, UK). The relative protein expression level was expressed as a ratio over $\beta$-actin.

ELISA analysis of PAF. Platelet-activating factor released into the cell culture media was measured by a ELISA Kit (Westang Biotech, Shanghai, China) according to the manufacture's protocol.

RNA interferences. For knockdown of $\beta$-catenin gene, sequencespecific siRNA targeting human $\beta$-catenin (sense $5^{\prime}$-UUUCAAAA CAGUUGUAUGGUA- $3^{\prime}$ and antisense $5^{\prime}$-CCAUACAACUGUU UUGAAAAU- $3^{\prime}$ ) was designed and synthesised by Gene Pharma (Shanghai, China). The following siRNA sense $5^{\prime}$-UUCUCCGAACGUGUCACGUTT-3'; and antisense $5^{\prime}$-ACGU GACACGUUCGGAGAATT- $3^{\prime}$ were used as a control. The cultured PC-3 cells were transfected with siRNA- $\beta$-catenin and siRNA-negative control using Lipofectamine 2000 (Invitrogen). The cells were then treated with DHT. Production of PAF was measured by ELISA as mentioned above.

Statistics. For illustrative purposes, the results are presented as the mean percent control \pm s.e.m. One-way ANOVA followed by the Student-Newman-Keuls test was used to assess significant differences between each two groups. Significance was set at $P<0.05$.

\section{RESULTS}

Identification of LPCAT1 in clinical specimens. Nine localised prostate cancer tissue specimens from patients undergoing radical prostatectomy were immunostained with LPCAT1 antibody. Positive staining was located mainly in cytoplasm of cancerous cells, and was stronger than normal prostate cells (Figure 1A and B).
The mRNA expression of LPCAT1 was also significantly higher in tumour samples than in the paired nontumour samples (Supplementary Figure 1). To investigate the potential biological and clinical role of LPCAT1 in prostate cancer from ADPC to CRPC stage, we investigated the expression level of LPCAT1 in six CRPC specimens derived from TURP, and their matched ADPC biopsy specimens. The protein expression of LPCAT1 significantly increased in CRPC specimens (5 in 6 samples) compared with their matched ADT-naive specimens (Figure $1 \mathrm{C}$ and D).

Effects of PAF on growth of prostate cancer cells. To further understand the potential role of PAF in the progression of prostate cancer, we determined the concentration of PAF in cultured LNCaP and PC-3 cells and found that PAF in PC-3 cells was significantly higher than that in LNCaP cells (Supplementary Figure 2). The expression of PAF receptor (PAF-R) in LNCaP cells, however, was comparable to the PC-3 cells (Figure 2A). When $\mathrm{LNCaP}$ and PC-3 cells were grown in the presence of increasing concentrations of PAF antagonist ABT- $491\left(10^{-8}-10^{-5} \mathrm{M}\right)$, a significant inhibition of proliferation was observed in both cells at concentrations between $10^{-7}$ and $10^{-5} \mathrm{M}$ (Figure 2B). Interestingly, treatment with PAF $\left(10^{-9}-10^{-6} \mathrm{M}\right)$ had no effect on proliferation of either LNCaP cells or PC-3 cells (Figure 2C).

Effects of PAF on mobility of prostate cancer cells. To determine whether PAF induces invasion of $\mathrm{LNCaP}$ and $\mathrm{PC}-3$ cells through a matrix-coated membrane, cells were exposed to increasing concentrations of PAF $\left(10^{-9}-10^{-6} \mathrm{M}\right)$ and PAF antagonist ABT- $491\left(10^{-8}-10^{-5} \mathrm{M}\right)$, or combinations of these agents. Invasion of PC-3 cells was increased by PAF in a concentration-dependent manner. At concentrations of $10^{-8} \mathrm{M}, 10^{-7} \mathrm{M}$ and $10^{-6} \mathrm{M}$, PAF induced a $51.4 \pm 4.37 \%, 77.6 \pm 5.92 \%$ and $118.0 \pm 10.49 \%$ increase in PC-3 invasion, respectively (Figure 3A). Treatment with ABT-491 inhibited tonic invasion of PC-3 cells (Figure 3B). Similarly, PC-3 cells treated by PAF also demonstrated a significant and concentration-dependent increase in migration. At concentrations of $10^{-8} \mathrm{M}$,
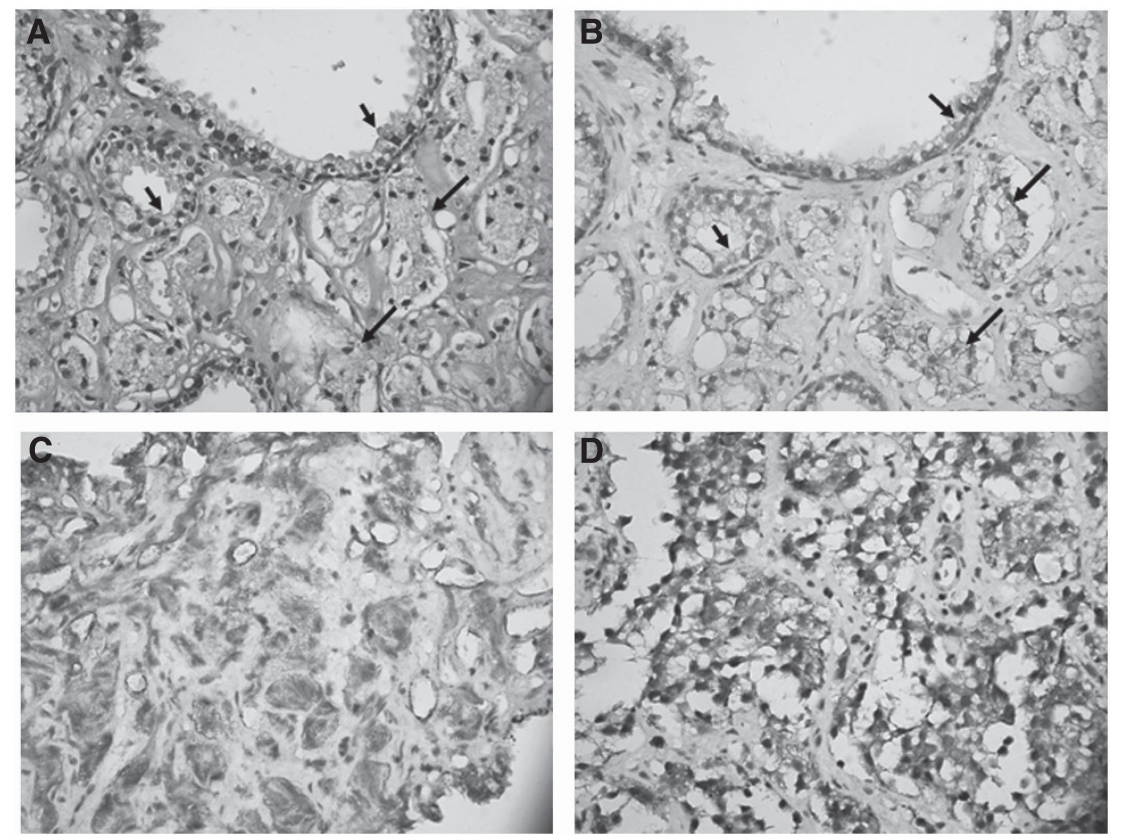

Figure 1. Immunolocalisation of LPCAT1 in human prostate cancer specimens. (A) Representative H\&E staining of a clinical prostate cancer sample (Gleason score $4+3=7$ ). (B) Protein expression of LPCAT1 in the same prostate cancer sample (Gleason score $4+3=7$ ) by immunohistochemistry: LPCAT1 protein expression of prostate adenocarcinoma cells was strong positive (long arrow), whereas that of normal prostate gland epithelial cells was negative or weak positive (short arrow). In a paired prostate cancer sample, LPCAT1 protein expression of tumour cells significantly increased from (C) ADT-naive biopsy specimen (Gleason score $3+4=7$ ) to (D) their matched CRPC specimen (Gleason score $4+4=8$ ). Original magnifications $\times 400(A-D)$. 
A

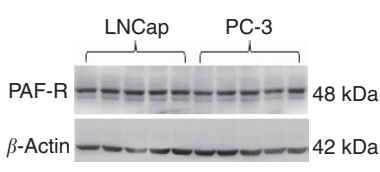

B

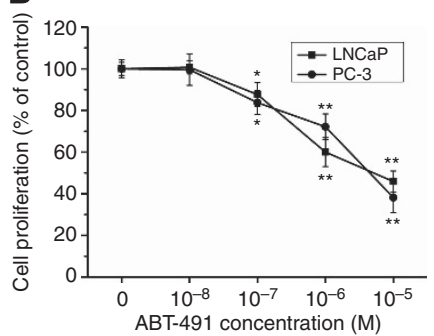

C

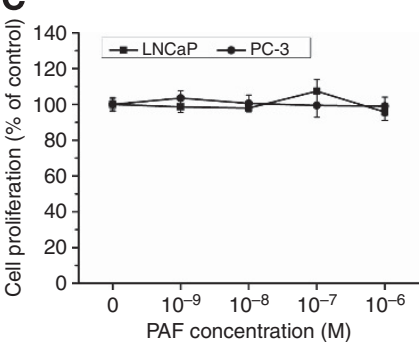

Figure 2. Effects of PAF and a specific PAF receptor antagonist ABT-491 on the proliferation of prostate cancer cells. (A) Expression of PAF receptor (PAF-R) in LNCaP cells and PC-3 cells was determined by western blot. (B) Prostate cancer cells were exposed to increasing concentrations of ABT-491. (C) Prostate cancer cells were treated with increasing concentrations of PAF for $24 \mathrm{~h}$. Values are presented as mean percent control \pm s.e.m. of six different experiments. ${ }^{\star} P<0.05$ and ${ }^{\star \star} P<0.01$ compared with control.
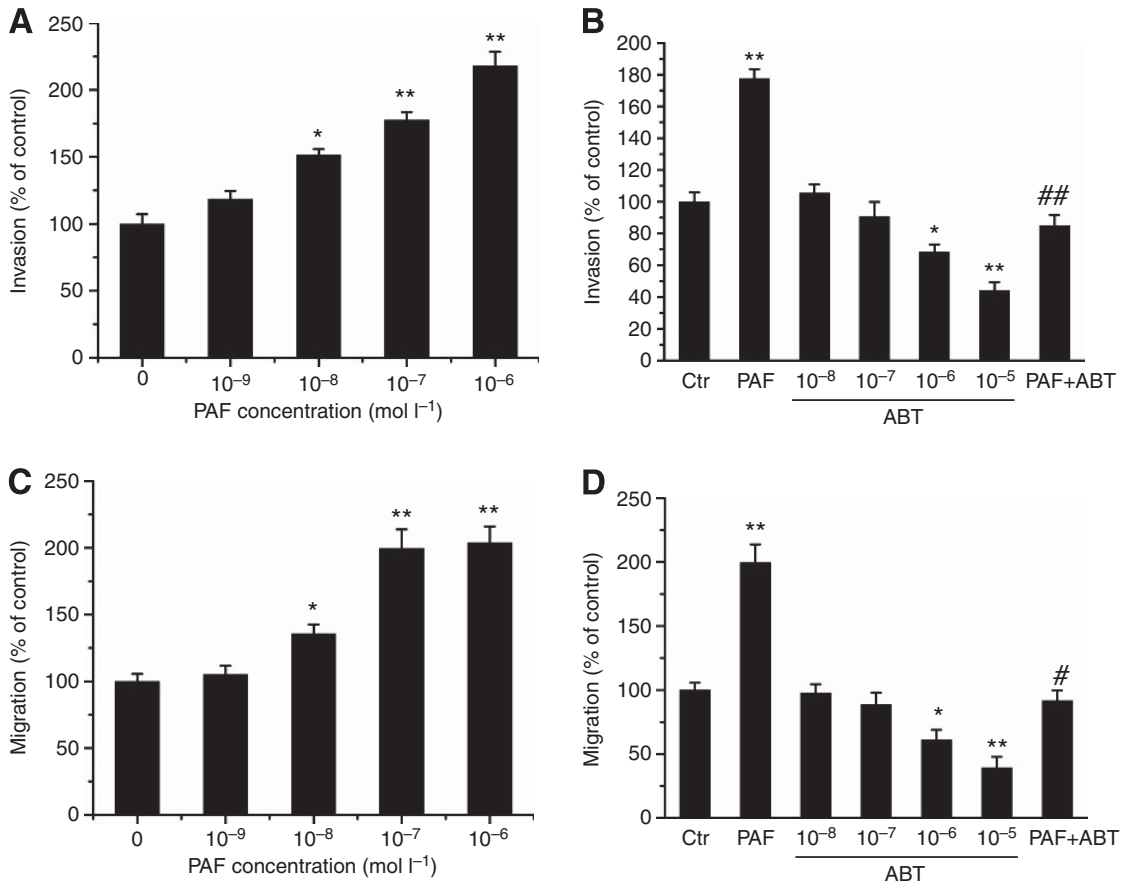

Figure 3. Effects of PAF and ABT-491 on invasion and migration of PC-3 cells. (A, C) Effects of increasing concentrations of PAF on invasion and migration of PC-3 cells. (B, D) Effects of increasing concentrations of ABT-491 on invasion and migration, and pretreatment with $A B T-491\left(10^{-5} \mathrm{M}\right)$ on PAF-induced invasion/migration of PC-3 cells. Data are presented as mean percent control \pm s.e.m. for five cultures $(n=5)$ performed in triplicate. ${ }^{\star} P<0.05$ and ${ }^{* \star} P<0.01$ compared with control; ${ }^{\#} P<0.05$ and ${ }^{\# \#} P<0.01$ compared with PAF treatment alone $\left(10^{-7} \mathrm{M}\right)$.

$10^{-7} \mathrm{M}$ and $10^{-6} \mathrm{M}$, PAF treatment caused an increase in migration to $135.68 \pm 6.91 \%, 199.67 \pm 14.1 \%$ and $203.88 \pm 12.13 \%$ of control, respectively (Figure 3C). Migration of PC-3 cells induced by PAF was likewise inhibited by the inclusion of ABT-491 $\left(10^{-5} \mathrm{M}\right.$; Figure 3D). In contrast, PAF did not affect invasion and migration of the androgen-dependent LNCaP cells (Supplementary Figure 3).

To confirm the significant attenuation of invasion and migration observed in PC-3 cells treated with PAF receptor antagonist ABT-491 did not result from a nonspecific loss of cellular viability, PC-3 cells were subjected to a cellular viability assay. As seen in Supplementary Figure 4, treatment of PC-3 with $10^{-5} \mathrm{M}$ ABT-491 resulted in a nonsignificant loss of viability during $24 \mathrm{~h}$ of incubation. The decrease in viability of $<10 \%$ at each time point is unlikely to account for the $56.8 \%$ attenuation of invasion and the $60.82 \%$ attenuation of migration.

Effects of androgen and other steroid hormones on PAF synthesis and production. Both androgen-dependent LNCaP cells and CRPC-3 cells have been shown to express LPCAT1 and produce PAF endogenously. To determine whether the expression of LPCAT1 and production of PAF is regulated by androgen and other steroid hormones, LNCaP and PC-3 cells were treated with increasing concentrations of DHT, oestrogen and progesterone, alone or with their receptor antagonists. Intriguingly, DHT resulted in a dose-dependent decrease in the mRNA and protein expression of LPCAT1 in LNCaP cells (Figure 4A), whereas it had a dose-dependent increase in PC-3 cells (Figure 4B). Maximal effects were both observed at $10^{-6} \mathrm{M}$ of DHT, which decreased LPCAT1 mRNA level to $46.21 \pm 6.48 \%$ and protein level to $34.37 \pm 6.14 \%$ of control in LNCaP cells, and increased LPCAT1 mRNA level to $345.49 \pm 43.98 \%$ and protein level to $233.71 \pm 26.41 \%$ of control in PC-3 cells, respectively. The concentration of PAF released into cell culture appeared to correlate well with the decrease or increase in the expression of enzyme protein (Figure 4C and D).

Downregulation of LPCAT1 expression and PAF release by DHT in LNCaP cells was reversed by steroid receptor antagonist RU486 and specific androgen receptor antagonist flutamide (Figure 4A and C). Intriguingly, RU486 and flutamide did not antagonise the effect of DHT in PC-3 cells (Figure 4B and D), indicating that androgen may not act through the traditional steroid receptors in PC-3 cells. 

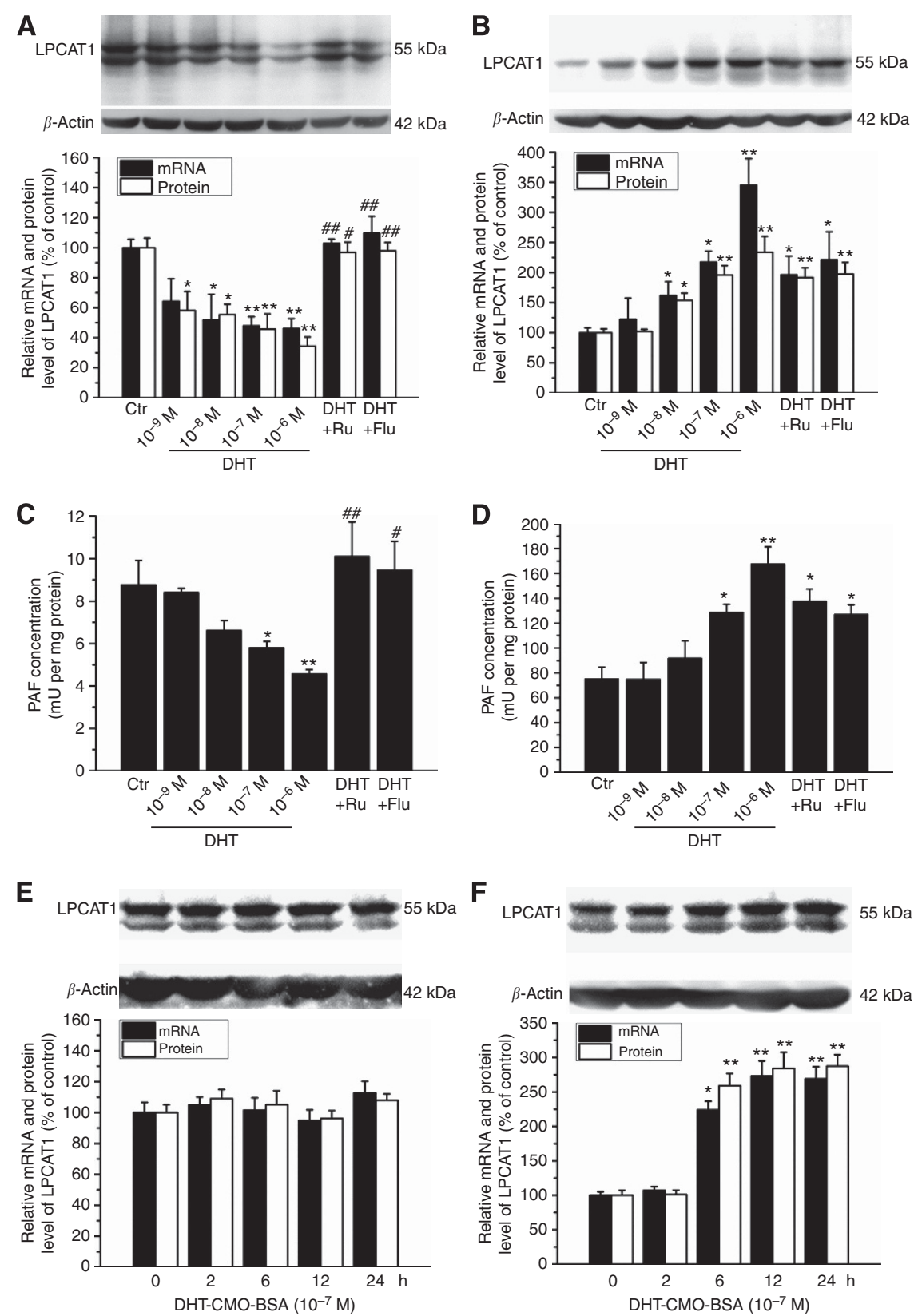

Figure 4. Effects of DHT on LPCAT1 mRNA and protein expression and PAF release in prostate cancer cells. Cells were treated with increasing concentration of DHT, and in combination of DHT $\left(10^{-7} \mathrm{M}\right)$ and RU486 $\left(10^{-6} \mathrm{M}\right)$ or flutamide $\left(10^{-6} \mathrm{M}\right)$ for $24 \mathrm{~h}$. The mRNA and protein levels of LPCAT1 in LNCaP cells (A) and PC-3 cells (B) were measured by real-time RT-PCR and western blot analysis, respectively. Representative protein bands were presented on the top of corresponding histogram. Concentrations of PAF in LNCaP (C) and PC-3 (D) cell culture were determined by ELISA. Time course expression of LPCAT1 in LNCaP cells (E) and PC-3 cells (F) treated by DHT-CMO-BSA are also shown. Flu, flutamide; Ru, RU486.Values are presented as mean percent control \pm s.e.m. (A, B, E, F) or mean \pm s.e.m. (C, D) for five cultures performed in triplicate. ${ }^{\star} P<0.05$ and ${ }^{\star *} P<0.01$ compared with control; ${ }^{\#} P<0.05$ and ${ }^{\# \#} P<0.01$ compared with DHT $\left(10^{-7} \mathrm{~mol} / \mathrm{I}^{-1}\right)$.

To further investigate this AR-independent regulation of DHT on LPCAT1 expression, DHT-CMO-BSA, in which DHT is conjugated to BSA to prevent the permeability of DHT into the cell, was used to treat LNCaP and PC-3 cells. It was shown that DHT-CMO-BSA could increase the mRNA and protein expression of LPCAT1 in PC- 3 cells as early as $6 \mathrm{~h}$, whereas the expression of LPCAT1 in LNCaP cells was not affected by DHT-CMO-BSA (Figure 4E and $\mathrm{F}$ ).

Aside from the androgens, $17 \beta$-oestradiol $\left(10^{-7} \mathrm{M}\right)$ was found to decrease the expression of LPCAT1 and PAF release in both LNCaP and PC-3 cells, which was blocked by RU486 and oestrogen receptor (ER) $-\beta$ antagonist cyclofenil but not by ER- $\alpha$ antagonist MPP in each cell line (Figure 5). Progesterone at a concentration of
$10^{-7} \mathrm{M}$ did not significantly affect LPCAT1 expression and PAF release in LNCaP and PC-3 cells (data not shown).

Wnt/ $\beta$-catenin signalling pathway is involved in androgen effects on PAF in PC-3 cells. To investigate the possible signalling pathways mediating nontraditional genomic effects of androgen on PAF production in PC-3 cells, various protein kinase inhibitors were examined to see whether they affected DHT-induced PAF production. None of the inhibitors exhibited antagonistic effect on DHT-induced PAF production in PC-3 cells (Supplementary Table 2). Using transfection of siRNA to inhibit the expression of $\beta$-catenin, the critical molecular component of canonical Wnt signalling, significantly reversed the DHT-induced PAF production 

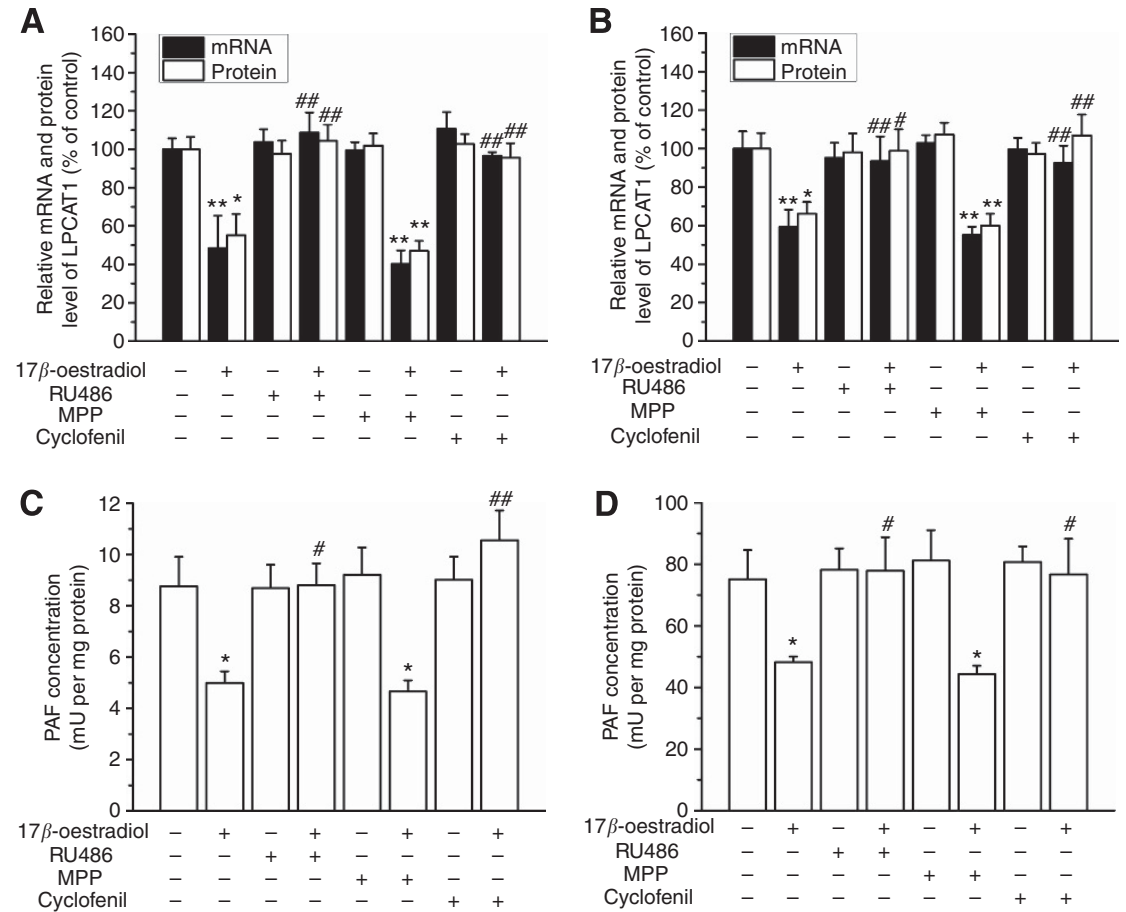

Figure 5. Effects of $17 \beta$-oestradiol on LPCAT1 mRNA and protein expression and PAF release in prostate cancer cells. Cells were treated with $17 \beta$-oestradiol $\left(10^{-7} \mathrm{M}\right)$ in the presence or absence of RU486 $\left(10^{-6} \mathrm{M}\right)$, MPP $\left(10^{-6} \mathrm{M}\right)$ and cyclofenil $\left(10^{-6} \mathrm{M}\right)$ for $24 \mathrm{~h}$. (A, C) LNCaP cells and (B, D) PC-3 cells. Values are presented as mean percent control \pm s.e.m. (A, B) or mean \pm s.e.m. (C, D) for five cultures performed in triplicate. ${ }^{\star} P<0.05$ and ${ }^{* \star} P<0.01$ compared with control; ${ }^{\#} P<0.05$ and ${ }^{\# \#} P<0.01$ compared with $17 \beta$-oestradiol $\left(10^{-7} \mathrm{~mol} / \mathrm{I}^{-1}\right)$.

in PC-3 cells (Figure 6A and B). Further western blot analysis confirmed that DHT could significantly promote the expression of $\beta$-catenin in PC-3 cells but not in LNCaP cells. Not so surprisingly, the elevated $\beta$-catenin in PC-3 cells could not be reversed by flutamide, the antagonist of DHT (Figure 6C).

\section{DISCUSSION}

Platelet-activating factor, a potent phospholipid second messenger found in high abundance in various human cancers, has unique pleiotropic biological properties in addition to platelet activation. This study demonstrated, for the first time, the production of PAF as well as the expression of its receptor PAF-R and synthetase LPCAT1 in human prostate cancer. The expression of LPCAT1 increased in prostate cancer tissue compared with matched tumourfree tissue, and further increased in CRPC specimens after ADT. Similarly, PAF produced by CRPC-3 cells is much higher than that produced by androgen-dependent LNCaP cells. These results suggested that endogenous PAF might exert biological functions on prostate cancer cells in a paracrine or autocrine manner, and play important roles in the transition from ADPC to CRPC.

Platelet-activating factor receptors have been identified in human breast cancer cells, pancreatic cancer cells and bladder cancer cells (Youlyouz et al, 2002). In our studies, we determined first the comparable protein expression of PAF-R in both LNCaP cells and PC-3 cells. The PAF-R antagonist ABT-491 was shown to inhibit LNCaP and PC-3 cell proliferation, which is consistent with a previous discovery that specific PAF-R antagonist, Y-24180, inhibited cell proliferation in a concentration-dependent manner in prostate cancer cells (Jan and Chao, 2004). These results indicate that endogenously produced PAF mediate a tonic growth of LNCaP and PC-3 cells. The fact that exogenous PAF had no effect on proliferation of LNCaP or PC-3 cells might suggest that PAF may be a second messenger rather than a primary message involved in signalling cascades leading to cellular proliferation. The potential exact mechanism, however, needs further research work in future.

In this study, we demonstrated that PAF signalling is directly involved in PC-3 cell invasion and migration, similar with previous conclusions in human umbilical vein endothelial cells (HUVECs) and breast cancer (Bussolati et al, 2000; Axelrad et al, 2004), indicating that the PAF signalling cascade alone is sufficient to induce invasion and migration. In HUVECs, PAF increases the ratio of active/inactive membrane type 1 matrix metalloproteinase (MT1-MMP) and thus results in increased activation of MMP2, the key enzyme that regulates degradation of extracellular matrix and facilitates invasion. Whether the mechanism underlying PAF-induced invasion in PC-3 cells is also related with activation of MMP2 needs further investigation. Otherwise, PAF was shown to increase COX-2 expression and its downstream substance $\mathrm{PGE}_{2}$ production in oesophageal squamous cell carcinoma (Wang et al, 2002). In the oncogenesis and angiogenesis of prostate cancer, $\mathrm{PGE}_{2}$ plays a crucial role via a number of mechanisms, such as resulting in increased proliferation and decreased apoptosis in androgen-sensitive and insensitive prostate cancer cells (Uotila et al, 2001; Jain et al, 2008; Patel et al, 2008). It is interesting to further investigate if PAF could indirectly regulate prostate cancer cells proliferation and invasion via bypass way of induced COX-2 and $\mathrm{PGE}_{2}$ production.

Despite the awareness of the important role of AR signalling in prostate cancer, the exact effect of ADT on AR signalling has not been well characterised. In this study, we expand our understanding that PAF may be a new potential signalling message involved in mechanisms underlying androgen and steroids effects on prostate cancer cells. The expression of LPCAT1 and the production of PAF were downregulated by DHT treatment and reversed by steroid receptor antagonist RU486 and specific androgen antagonist ABT-491 in serum and phenol-free (androgen free) $\mathrm{LNCaP}$ cultures. This suggested that androgen may exert a tonic inhibitory effect on PAF release in ADPC cells in an AR-dependent manner. Androgen deprivation therapy impairs this tonic inhibition and makes PAF increase dramatically, which offsets 

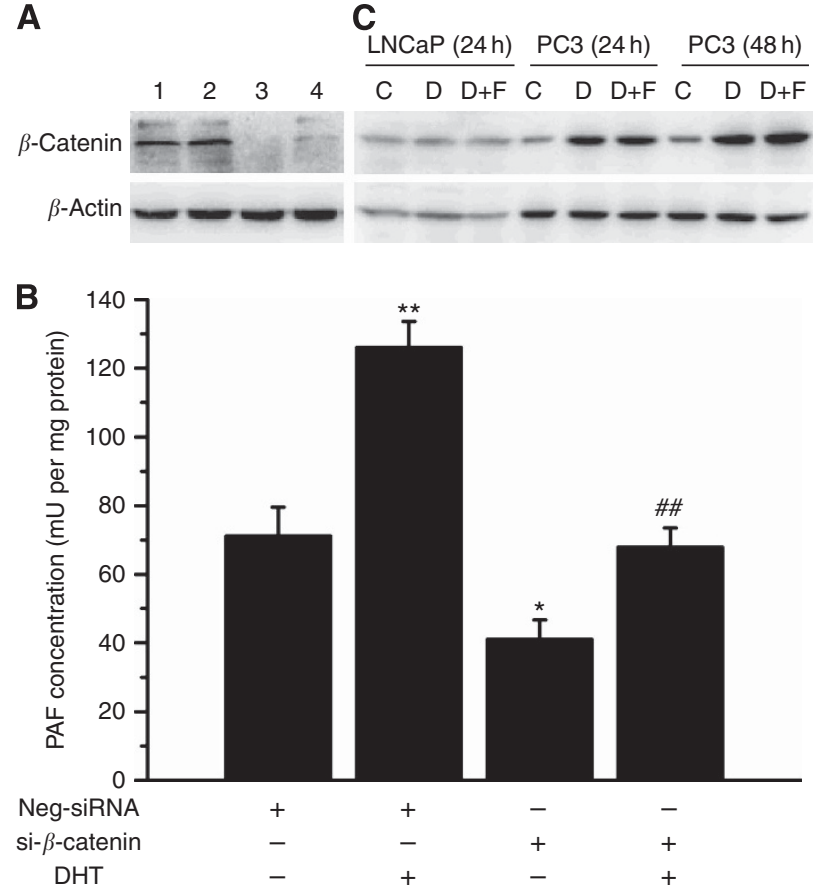

Figure 6. Dihydrotestosterone-induced PAF release in $\beta$-catenin knockdown PC-3 cells. (A) Representative bands for protein expression of $\beta$-catenin in cells transfected with $\beta$-catenin siRNA. $(1,2)$ Cells transfected with Neg-siRNA; $(3,4)$ cells transfected with $\beta$-cateninspecific siRNA. (B) Effects of $\beta$-catenin knockdown on PAF release in PC-3 cells in the presence or absence of DHT $\left(10^{-7} \mathrm{M}\right)$. Values are presented as mean \pm s.e.m.; $n=4$. ${ }^{*} P<0.05$ and ${ }^{*} * P<0.01$ compared with negative control siRNA; ${ }^{\# \#} P<0.01$ compared with DHT $\left(10^{-7} \mathrm{M}\right)$ treatment in cells transfected with negative control siRNA.

(C) Representative bands for protein expression of $\beta$-catenin in LNCaP cells and PC-3 cells. Cells were treated with DHT $\left(10^{-7} \mathrm{M}\right)$ in the absence or presence of flutamide $\left(10^{-6} \mathrm{M}\right)$ for $24 \mathrm{~h}$ ( $\mathrm{LNCaP}$ and PC-3 cells) or $48 \mathrm{~h}(\mathrm{PC}-3$ cells). C (control), 1:10000 ethanol in PBS; D, DHT; F, flutamide.

therapeutic actions elicited by ADT, partially if not all. Meanwhile, the increasing PAF after androgen deprivation may act as an important signalling message to facilitate the transition to an aggressive phenotype of CRPC. In contrast, treatment of DHT in CRPC- 3 cells increased LPCAT1 expression and PAF production in a rapid and AR-independent manner. Nongenomic actions of androgens have been previously described in prostate cancer cells. Tong and Tai (2000) have reported that ERK kinase inhibitor and tyrosine kinase inhibitor attenuated androgen-induced 15-PGDH expression that was also shown to be AR independent. The sequential responses to hormonal manipulation, known as secondary hormonal therapy, also relies on the fact that CRPC is not necessarily androgen independent and is susceptible to further hormonal manipulation (Reis, 2012). Abiraterone, a CYP17 inhibitor that effectively blocks the conversion of androgens from nongonadal precursors, thus reducing testosterone to undetectable levels, has recently been proved to prolonged overall survival among patients with metastatic CRPC even after previous chemotherapy (de Bono et al, 2011). Although better evidence is necessary, the present study also supports the rationale of an important role for androgen depletion, as low-level DHT can promote malignant CRPC cells progression through $\mathrm{Wnt} / \beta$-catenin pathway.

Androgen signalling is now known to be influenced by several other signal transduction pathways, and these points of crosstalk might be key factors of the abnormal behaviour of the prostate cells in disease states. Wnt is a complex signalling pathway whose end point involves activation of transcription from LEF-1/TCF transcription factors and it is known to be involved in the development and progression of numerous human epithelial tumours including prostate cancer. $\beta$-Catenin protein, a particularly critical molecular component of canonical Wnt signalling, is now known to promote androgen signalling through its ability to directly bind to the AR protein and to enhance the ability of liganded AR to activate transcription of androgen-regulated genes (Truica et al, 2000; Pawlowski et al, 2002; Song et al, 2003; Masiello et al, 2004). Several different studies have reported an upregulation in the expression of Wnt ligands and $\beta$-catenin in cancer cells compared with normal prostate cells (McKiernan and Benson, 2004; Ricke et al, 2008). In our study, knockdown of $\beta$-catenin in PC-3 cells significantly decreased production of PAF supported this previous work, and led us to hypothesise that increase of Wnt ligands and $\beta$-catenin in prostate cancer cells may promote cell proliferation and invasion by inducing PAF production. Here we further demonstrated that $\beta$-catenin was not influenced by DHT in LNCaP cells but significantly elevated in DHT-treated PC-3 cells, which could not be reversed by the antagonist of DHT. Knockdown of $\beta$-catenin in PC-3 cells significantly decreased the production of PAF induced by DHT supported the important role of $\beta$-catenin in the regulation of DHT on PAF in PC- 3 cells. These results suggested that in $\mathrm{PC}-3$ cells, $\beta$-catenin interacts with $\mathrm{AR}$ signalling pathways on regulation of PAF, even though the effect seems to be AR independent. Androgen regulation on PAF release in a Wnt/ $\beta$-catenin-dependent pathway in CRPC stage may partially contribute to its development. However, in this study we did not find an obvious variation in the expression and activation of LEF-1/TCF, one of the validated downstream transcription factors of $\mathrm{Wnt} / \beta$-catenin pathway (data not shown). Further studies on the cross-talk between $\mathrm{AR}$ and $\mathrm{Wnt} / \beta$-catenin signalling pathway are needed so as to identify underlying mechanism of CRPC that may finally lead to new strategies to neutralise aggressive CRPC.

Oestrogen is used as a second-line hormone therapy for prostate cancer, based on its indirect suppression of androgen levels. It is known that oestrogens acting via ER $\alpha$ mediate aberrant epithelial cell proliferation, prostatic inflammation and malignancy (Imamov et al, 2004; Ricke et al, 2008; Setlur et al, 2008). In contrast, effects of oestrogen mediated by ER $\beta$ are beneficial. Previous studies have reported anti-proliferative and pro-apoptotic activity of $\operatorname{ER} \beta$ agonist in the prostate, independent of systemic androgens, targeting castrate-resistant epithelial cells (Weihua et al, 2002; Imamov et al, 2004; McPherson et al, 2008; Ricke et al, 2008; McPherson et al, 2010). Likewise, in this study, we presented that $17 \beta$-oestradiol could decrease the expression of LPCAT1 and PAF release in both $\mathrm{LNCaP}$ and PC-3 cells via $\mathrm{ER} \beta$-mediated pathway. It provides a new line that beneficial effects of $\operatorname{ER} \beta$ activation could also be mediated by the downregulation of proliferative and invasive signalling message, namely PAF, other than previously uncovered TNF- $\alpha$ pathway, either in ADPC or CRPC cells. In the latter circumstance, ER $\beta$ agonist may offer some therapeutic advantage other than castration. Although ER (as well as PR and GR) has not been identified to have a similar interaction with $\beta$-catenin as $\mathrm{AR}$ (Pawlowski et al, 2002), the mechanism underlying $\operatorname{ER} \beta$ effect on $\mathrm{PAF}$ is likely to be classical genomic response.

In conclusion, androgen differentially regulates LPCAT1 and PAF expression in androgen-dependent LNCaP cells and CRPC-3 cells via different signalling pathways. The increase of PAF after castration may play an important role in transition from ADPC to CRPC, and further accelerate the progression of aggressive phenotype of CRPC cells. This study indicates the potential clinical application of PAF antagonist, either alone or in combination with existing androgen blockade, may be potentially effective for the prevention of the emergence and development of CRPC. 


\section{ACKNOWLEDGEMENTS}

This work is supported by National Natural Science Foundation of China (No. 30901502 and No. 81170596), Shanghai Natural Science Foundation (13ZR1409800) and 2013 Army Medical Science Youth Training Project.

\section{CONFLICT OF INTEREST}

The authors declare no conflict of interest.

\section{REFERENCES}

Axelrad TW, Deo DD, Ottino P, Van Kirk J, Bazan NG, Bazan HE, Hunt JD (2004) Platelet-activating factor (PAF) induces activation of matrix metalloproteinase 2 activity and vascular endothelial cell invasion and migration. FASEB J 18(3): 568-570.

Bussolati B, Biancone L, Cassoni P, Russo S, Rola-Pleszczynski M, Montrucchio G, Camussi G (2000) PAF produced by human breast cancer cells promotes migration and proliferation of tumor cells and neo-angiogenesis. Am J Pathol 157(5): 1713-1725.

de Bono JS, Logothetis CJ, Molina A, Fizazi K, North S, Chu L, Chi KN, Jones RJ, Goodman Jr OB, Saad F, Staffurth JN, Mainwaring P, Harland S, Flaig TW, Hutson TE, Cheng T, Patterson H, Hainsworth JD, Ryan CJ, Sternberg CN, Ellard SL, Fléchon A, Saleh M, Scholz M, Efstathiou E, Zivi A, Bianchini D, Loriot Y, Chieffo N, Kheoh T, Haqq CM, Scher HI. COU-AA-301 Investigators (2011) Abiraterone and increased survival in metastatic prostate cancer. N Engl J Med 364(21): 1995-2005.

Dreicer R, Gleave M, Kibel AS, Thrasher JB, Moul JW (2011) Targeting the androgen receptor-theory and practice. Urology 78(5 Suppl): S482-S484.

Enayetallah AE, French RA, Grant DF (2006) Distribution of soluble epoxide hydrolase, cytochrome $\mathrm{P} 450$ 2C8, 2C9 and 2J2 in human malignant neoplasms. J Mol Histol 37(3-4): 133-141.

Grasso CS, Wu YM, Robinson DR, Cao X, Dhanasekaran SM, Khan AP, Quist MJ, Jing X, Lonigro RJ, Brenner JC, Asangani IA, Ateeq B, Chun SY, Siddiqui J, Sam L, Anstett M, Mehra R, Prensner JR, Palanisamy N, Ryslik GA, Vandin F, Raphael BJ, Kunju LP, Rhodes DR, Pienta KJ, Chinnaiyan AM, Tomlins SA (2012) The mutational landscape of lethal castration-resistant prostate cancer. Nature 487(7406): 239-243.

Imamov O, Morani A, Shim GJ, Omoto Y, Thulin-Andersson C, Warner M, Gustafsson JA (2004) Estrogen receptor beta regulates epithelial cellular differentiation in the mouse ventral prostate. Proc Natl Acad Sci USA 101(25): 9375-9380.

Jain S, Chakraborty G, Raja R, Kale S, Kundu GC (2008) Prostaglandin E2 regulates tumor angiogenesis in prostate cancer. Cancer Res 68(19): 7750-7759.

Jan CR, Chao YY (2004) Novel effect of Y-24180, a presumed specific platelet activation factor receptor antagonist, on $\mathrm{Ca} 2+$ levels and growth of human prostate cancer cells. Cell Signal 16(8): 959-965.

Masiello D, Chen SY, Xu Y, Verhoeven MC, Choi E, Hollenberg AN, Balk SP (2004) Recruitment of beta-catenin by wild-type or mutant androgen receptors correlates with ligand-stimulated growth of prostate cancer cells. Mol Endocrinol 18(10): 2388-4201.

McKiernan J, Benson MC (2004) Predicting the clinical course of prostate cancer. J Clin Invest 113(6): 806-808.

McPherson SJ, Ellem SJ, Risbridger GP (2008) Estrogen-regulated development and differentiation of the prostate. Differentiation 76(6): 660-760.

McPherson SJ, Hussain S, Balanathan P, Hedwards SL, Niranjan B, Grant M, Chandrasiri UP, Toivanen R, Wang Y, Taylor RA, Risbridger GP (2010) Estrogen receptor-beta activated apoptosis in benign hyperplasia and cancer of the prostate is androgen independent and TNFalpha mediated. Proc Natl Acad Sci USA 107(7): 3123-3128.

Muguruma K, Komatz Y, Ikeda M, Sugimoto T, Saito K (1993) Platelet-activating factor (PAF) in male reproductive organs of guinea pigs and rats: effect of androgen on PAF in seminal vesicles. Biol Reprod 48(2): 386-392.

Nie D, Guo Y, Yang D, Tang Y, Chen Y, Wang MT, Zacharek A, Qiao Y, Che M, Honn KV (2008) Thromboxane A2 receptors in prostate carcinoma: expression and its role in regulating cell motility via small GTPase Rho. Cancer Res 68(1): 115-121.

Patel MI, Kurek C, Dong Q (2008) The arachidonic acid pathway and its role in prostate cancer development and progression. J Urol 179(5): 1668-1675.

Pawlowski JE, Ertel JR, Allen MP, Xu M, Butler C, Wilson EM, Wierman ME (2002) Liganded androgen receptor interaction with beta-catenin: nuclear co-localization and modulation of transcriptional activity in neuronal cells. J Biol Chem 277(23): 20702-20710.

Reis LO (2012) Variations of serum testosterone levels in prostate cancer patients under LH-releasing hormone therapy: an open question. Endocr Relat Cancer 19(3): R93-R98.

Ricke WA, McPherson SJ, Bianco JJ, Cunha GR, Wang Y, Risbridger GP (2008) Prostatic hormonal carcinogenesis is mediated by in situ estrogen production and estrogen receptor alpha signaling. FASEB J 22(5): 1512-1520.

Sato SM, Johansen JA, Jordan CL, Wood RI (2010) Membrane androgen receptors may mediate androgen reinforcement. Psychoneuroendocrinology 35(7): 1063-1073.

Setlur SR, Mertz KD, Hoshida Y, Demichelis F, Lupien M, Perner S, Sboner A, Pawitan Y, Andrén O, Johnson LA, Tang J, Adami HO, Calza S, Chinnaiyan AM, Rhodes D, Tomlins S, Fall K, Mucci LA, Kantoff PW, Stampfer MJ, Andersson SO, Varenhorst E, Johansson JE, Brown M, Golub TR, Rubin MA (2008) Estrogen-dependent signaling in a molecularly distinct subclass of aggressive prostate cancer. $J$ Natl Cancer Inst 100(11): 815-825.

Siegel R, Naishadham D, Jemal A (2012) Cancer statistics, 2012. CA Cancer $J$ Clin 62(1): 10-29.

Song LN, Herrell R, Byers S, Shah S, Wilson EM, Gelmann EP (2003) Beta-catenin binds to the activation function 2 region of the androgen receptor and modulates the effects of the N-terminal domain and TIF2 on ligand-dependent transcription. Mol Cell Biol 23(5): 1674-1687.

Tong M, Tai HH (2000) Induction of NAD( + )-linked 15-hydroxyprostaglandin dehydrogenase expression by androgens in human prostate cancer cells. Biochem Biophys Res Commun 276(1): 77-81.

Truica CI, Byers S, Gelmann EP (2000) Beta-catenin affects androgen receptor transcriptional activity and ligand specificity. Cancer Res 60(17): 4709-4713.

Uotila P, Valve E, Martikainen P, Nevalainen M, Nurmi M, Härkönen P (2001) Increased expression of cyclooxygenase-2 and nitric oxide synthase-2 in human prostate cancer. Urol Res 29(1): 23-28.

Wang LS, Chow KC, Wu YC (2002) Effects of platelet activating factor, butyrate and interleukin- 6 on cyclooxygenase- 2 expression in human esophageal cancer cells. Scand J Gastroenterol 37(4): 467-475.

Weihua Z, Lathe R, Warner M, Gustafsson JA (2002) An endocrine pathway in the prostate, ERbeta, AR, 5alpha-androstane-3beta,17beta-diol, and CYP7B1, regulates prostate growth. Proc Natl Acad Sci USA 99(21): 13589-13594.

Xu B, Sun Y, Tang G, Xu C, Wang L, Zhang Y, Ji J (2009) Id-1 expression in androgen-dependent prostate cancer is negatively regulated by androgen through androgen receptor. Cancer Lett 278(2): 220-229.

Youlyouz I, Magnoux E, Guglielmi L, Denizot Y (2002) Expression of a splice variant of the platelet-activating factor receptor transcript 2 in various human cancer cell lines. Mediators Inflamm 11(5): 329-331.

Yu J, Akishita M, Eto M, Koizumi H, Hashimoto R, Ogawa S, Tanaka K, Ouchi Y, Okabe T (2012) Src kinase-mediates androgen receptor-dependent non-genomic activation of signaling cascade leading to endothelial nitric oxide synthase. Biochem Biophys Res Commun 424(3): 538-543.

This work is published under the standard license to publish agreement. After 12 months the work will become freely available and the license terms will switch to a Creative Commons AttributionNonCommercial-Share Alike 3.0 Unported License.

Supplementary Information accompanies this paper on British Journal of Cancer website (http://www.nature.com/bjc) 